\title{
Evaluation of epicardial fat tissue thickness and aortic stiffness in patients with gestational diabetes mellitus
}

\author{
Melike Nur Akın ${ }^{1}$ (D), Burcu Kasap ${ }^{1}$ (D) , Fatih Akın² (D), Burak Sezgin ${ }^{1}$ (D), İbrahim Altun ${ }^{2}$ \\ Aysun Camuzcuoğlü ${ }^{3}$ iD , Rüya Deveer ${ }^{1}$ (iD) , Nilgün Turhan ${ }^{4}$ \\ ${ }^{1}$ Department of Obstetrics \& Gynecology, School of Medicine, Muğla Sitkı Koçman University, Muğla, Turkey \\ ${ }^{2}$ Department of Cardiology, School of Medicine, Muğla Sitkı Koçman University, Muğla, Turkey \\ ${ }^{3}$ Obstetrics \& Gynecology Clinic, Private Adatıp Sakarya Hospital, Sakarya, Turkey \\ ${ }^{4}$ Private Clinic for Obstetrics \& Gynecology, İstanbul, Turkey
}

\begin{abstract}
Objective: We aimed to assess the relationship between gestational diabetes mellitus and coronary artery disease by measuring epicardial fat tissue thickness and aortic stiffness in pregnant women diagnosed with gestational diabetes mellitus.

Methods: 28 pregnant women diagnosed with gestational diabetes mellitus and 25 pregnant women without gestational diabetes mellitus were included in the research. Body mass index, laboratory values, blood pressure measurements and obstetric history findings of the study population were recorded. All participants of the study population were evaluated with transthoracic echocardiography between 24 and 28 weeks of gestational period. The measurement of epicardial fat tissue thickness was taken and aortic stiffness index was also calculated.

Results: The age, gravidity, parity and obstetric history of the two groups were similar. Epicardial fat tissue thickness was found significantly higher in gestational diabetes mellitus group than control group $(0.416 \mathrm{~cm}$ and $0.336 \mathrm{~cm}$, respectively; $\mathrm{p}<0.001)$. However, no significant difference was found in aortic stiffness measurements of the two groups $(\mathrm{p}=0.079)$.

Conclusion: According to the results of our study, epicardial fat tissue thickness was found to be statistically significantly higher in pregnant women with gestational diabetes mellitus compared to the control group. The fact that no difference was detected in other cardiovascular parameters suggests that measurement of epicardial fat tissue thickness in gestational period may be a beneficial adjunctive tool in early detection of gestational diabetes mellitus.
\end{abstract}

Keywords: Gestational diabetes mellitus, epicardial fat tissue, aortic stiffness.

\section{Özet: Gestasyonel diabetes mellitus hastalarında epikardiyal yağ dokusu kalınlığı ve aortik sertliğin değerlendirilmesi}

Amaç: Çalışmamızda, gestasyonel diabetes mellitus tanısı almış gebelerde epikardiyal yağ dokusu kalınlığını ve aortik sertliği ölçerek gestasyonel diabetes mellitus ile koroner arter hastalığı arasındaki ilişkiyi değerlendirmeyi amaçladık.

Yöntem: Çalışmaya gestasyonel diabetes mellitus tanısı almış 28 gebe ve gestasyonel diabetes mellitusu olmayan 25 gebe dahil edildi. Çalışma popülasyonunun vücut kitle indeksi, laboratuvar değerleri, kan basıncı ölçümleri ve obstetrik hikaye bulguları kaydedildi. Çalışmaya katılan tüm olgular gebeliğin 24 ve 25 . haftaları arasında transtorasik ekokardiyografi ile değerlendirildi. Epikardiyal yağ dokusu kalınlığı ölçümü alındı ve aortik sertlik indeksi hesaplandi.

Bulgular: Yaş, gravida, parite ve obstetrik hikaye bakımından iki grup benzerdi. Epikardiyal yağ dokusu kalınlığı, kontrol grubuna kıyasla gestasyonel diabetes mellitus grubunda anlamlı şekilde daha yüksekti (sırasıyla $0.336 \mathrm{~cm}$ ve $0.416 \mathrm{~cm}$; $\mathrm{p}<0.001$ ). Ancak, iki grubun aortik sertlik ölçümleri arasında hiçbir anlamlı fark yoktu $(\mathrm{p}=0.079)$.

Sonuç: Çalışmamızın sonuçlarına göre epikardiyal yağ dokusu kalınlığı, kontrol grubuna kıyasla gestasyonel diabetes mellituslu gebelerde istatistiksel olarak anlamlı şekilde daha yüksekti. Diğer kardiyovasküler parametrelerde hiçbir farklılı̆̆ın bulunmaması, gestasyonel dönemde epikardiyal yağ dokusu kalınlığı ölçümünün gestasyonel diabetes mellitusun erken tespitinde faydalı bir ek araç olabileceğine işaret etmektedir.

Anahtar sözcükler: Gestasyonel diabetes mellitus, epikardiyal yă̆ dokusu, aortik sertlik.

Correspondence: Melike Nur Akın, MD. Department of Obstetrics \& Gynecology, School of Medicine, Muğla Sıtkı Koçman University, Muğla, Turkey. e-mail: drmelikenur80@hotmail.com / Received: January 4, 2021; Accepted: January 25, 2021

How to cite this article: Akın MN, Kasap B, Akın F, Sezgin B, Altun İ, Camuzcuoğlu A, Deveer R, Turhan N. Evaluation of epicardial fat tissue thickness and aortic stiffness in patients with gestational diabetes mellitus. Perinatal Journal 2021;29(1):33-38. doi:10.2399/prn.21.0291006

ORCID ID: M. N. Akın 0000-0001-6794-846X; B. Kasap 0000-0002-1768-5320; F. Akın 0000-0003-4865-8947; B. Sezgin 0000-0003-2938-5816; İ. Altun 0000-0002-5916-614X; A. Camuzcuoğlu 0000-0002-7362-8785; R. Deveer 0000-0002-4445-8086; N. Turhan 0000-0002-9084-0630 


\section{Introduction}

Gestational diabetes mellitus (GDM) is a carbohydrate tolerance disorder that was detected during gestational period. $^{[1,2]}$ The incidence of GDM varies from $1 \%$ to $14 \% .^{[3,4]}$ GDM is not only a pregnancy-related disease, but also patients with GDM have the risk of $17.06 \%$ for studies with follow-up of one to five years developing type 2 diabetes mellitus. ${ }^{[5]}$ Insulin resistance is the main cause of GDM and it is also related with cardiovascular diseases. ${ }^{[3]}$ Insulin resistance leads to chronic inflammation, which results in atherosclerosis, which also makes pregnant women a candidate for cardiovascular disease. ${ }^{[6]}$ It is aimed to predict cardiovascular risk in women complicated with GDM by detecting preclinical markers of atherosclerosis before the development of type $2 \mathrm{DM}$.

Epicardial fat tissue is the visceral adipose tissue of the heart and is derived from brown adipose tissue during embryogenesis, which creates a defensive system against cardiac hypothermia. ${ }^{[7,8]}$ The defensive system is to absorb free fatty acids when they are high in the circulatory system and work as an energy resource as the energy demand increases. ${ }^{[9]}$ Epicardial adipose tissue secretes many proinflammatory and proatherogenic cytokines including vasoactive peptides so it is metabolically very active. These cytokines were found to be associated with obesity, hypertension and coronary heart disease. ${ }^{[10,11]}$ Epicardial fat tissue thickness (EFTT) is a useful and noninvasive method for predicting cardiovascular diseases. EFTT measurement is practical, inexpensive and effective. EFTT can be evaluated very well by transthoracic echocardiography. It has also been reported to increase in patients with diabetes mellitus and insulin resistance. ${ }^{[12]}$ There are also researches investigating the relationship between GDM and EFTT ${ }^{[1,14]}$ But these studies have reported some conflicting results.

The impact of cardiovascular risk factors on circulatory system has been the subject of many studies. As a result of the structural changes in the large vessels due to these risk factors, it is now clear that these vessels are stiffened, in other words, they are exposed to "stiffness". It has been found that this process directly affects cardiovascular morbidity and mortality, especially with "stiffness" studies in large vessels in the literature. ${ }^{[15]}$ EFTT has been also found to be related with arterial stiffness. ${ }^{[16]}$ In most studies examining the aortic stiffness, the pulse wave velocity (PWV) was used as the "stiffness" index that was measured invasively or non-invasively in these studies. ${ }^{[17,18]}$
Aortic stiffness is usually measured with echocardiography. Aortic "strain", beta index and aortic "distensibility" calculated by echocardiographic aortic diameter and sphygmomanometric blood pressure measurements have been proposed to measure aortic stiffness. ${ }^{[19]}$ In this research, our goal was to find the relationship between GDM and coronary artery disease by measuring EFTT and aortic stiffness in pregnant women with GDM.

\section{Methods}

The ethical approval was obtained from the Clinical Research Ethics Committee of Muğla Sttkı Koçman University School of Medicine for the study (Ethics Committee Approval Number 25.05.2015 / 12). Twostep GDM screening was performed to diagnose GDM in pregnant women between 24 and 28 weeks of gestation who applied to the Gynecology and Obstetrics outpatient clinic of Muğla Sitkı Koçman University Hospital. First, 50-g oral glucose tolerance test (OGTT) was applied on the pregnant women as screening test. 100-g OGTT was applied to those whose 1st hour blood glucose level was over $140 \mathrm{~g} / \mathrm{dl}$ as diagnostic test. Among the 100-g OGTT results, 28 patients were confirmed as GDM and included in GDM group (study group). Threshold levels of 100-g OGTT were determined according to The National Diabetes Data Group (NDDG) standards (fasting value: $105 \mathrm{mg} / \mathrm{dL}$, 1st hour value: $190 \mathrm{mg} / \mathrm{dL}$, 2nd hour value: $165 \mathrm{mg} / \mathrm{dL}$ and $3 \mathrm{rd}$ hour value: $145 \mathrm{mg} / \mathrm{dL}$ ). ${ }^{[20]} 25$ patients were included in the control group whose 50-g OGTT's within normal limits (control group). Laboratory values, height $(\mathrm{cm})$, weight $(\mathrm{kg})$, blood pressure measurements and obstetric history findings of the patients were recorded.

Transthoracic echocardiography examination was performed in all participants between 24 and 28 weeks of gestation using a $2.5-3.5 \mathrm{MHz}$ ultrasound probe in the left lateral lying position (Vivid 7, GEVingmed Ultrasound AS, Horten, Norway). All echocardiographic scans were performed by a cardiologist expert in echocardiography, who was blinded to the patient's clinical data and digitally recorded including at least three heartbeats. Standard echocardiographic measurements such as left atrium size, left ventricle diameter, left ventricular wall thickness and left ventricular ejection fraction were performed in accordance with the American Echocardiography Association guidelines. Epicardial adipose tissue was detected as an area of relatively low 
echogenicity located between the right ventricle and the inner leaf of the pericardium. The thickest EFT was measured in the end-systolic phase of the cardiac cycle, parallel to the aortic valve from this area. ${ }^{[21]}$ The aortic strain, distensibility and aortic stiffness index (ASI) were taken as aortic elasticity parameters. ${ }^{[2]}$

The following formulas were used to calculate these parameters:

Aortic Strain (\%) = (systolic diameter-diastolic diameter) $\times 100 /$ diastolic diameter,

Aortic Stiffness Index (ASI) $=\ln$ (systolic pressure / diastolic pressure) / aortic strain,

Distensibility $\left(\mathrm{cm}^{2} \cdot \mathrm{dyn}^{-1}\right)=(2 \times$ aortic strain $) /($ systolic pressure - diastolic pressure)

The normal distribution suitability of continuous variables was analyzed using Shapiro-Wilk test. Independent samples $t$ test (for normal data) and MannWhitney $U$ test (for not normally distributed data) were used for comparison of two independent groups, and mean and standard deviation were given as descriptive statistics. The obtained data were evaluated using SPSS for Windows version 22.0 (SPSS Inc., Chicago, IL, USA). Differences were considered significant at a pvalue of less than 0.05 .

\section{Results}

The clinical characteristics and laboratory findings of the groups included in the study are presented in Table 1. The participants in two groups were similar in terms of age, gravidity, parity and obstetric history of abortion, smoking, gestational diabetes mellitus. Fasting blood glucose levels and 50-g OGTT results of the groups were statistically significantly different $(p=0.003$ and $p<0.001$, respectively). There was a significant difference between the 1st hour and 2nd hour blood glucose levels of the patients who underwent 100 -g OGTT in the groups $(\mathrm{p}<0.001$ and $\mathrm{p}=0.006$, respectively). Body mass index values were found to be higher in the GDM group compared to the control group (24.7 and 29.6, respectively).

EFTT was significantly higher in the GDM group compared to the control group (0.336 and 0.416 respectively, $\mathrm{p}<0.001$ ) (Table 2 ). While there was no difference in systolic blood pressures between the groups, diastolic blood pressures of patients with GDM were found to be higher $(\mathrm{p}=0.009)$. In multivariate linear regression analysis, a weak correlation was found between diastolic blood pressure and EFTT $(p=0.04, r=0.307)$. However, there was no significant difference in aortic stiffness measurements between the

Table 1. Demographic characteristics of the study population.

\begin{tabular}{|c|c|c|c|}
\hline & $\begin{array}{l}\text { GDM group }(n=28) \\
\text { Mean } \pm S D\end{array}$ & $\begin{array}{c}\text { Control group }(n=25) \\
\text { Mean } \pm \text { SD }\end{array}$ & p-value \\
\hline Age (years) & $26 \pm 0.4$ & $21 \pm 0.5$ & $0.297^{*}$ \\
\hline Body mass index $\left(\mathrm{kg} / \mathrm{m}^{2}\right)$ & 29.6 & 24.7 & $0.001 *$ \\
\hline Gravidity & $2.4 \pm 1.3$ & $2.4 \pm 1.3$ & $0.741^{+}$ \\
\hline Parity & $0.8 \pm 0.9$ & $1.1 \pm 1.1$ & $0.235^{+}$ \\
\hline No. of abortions & $0.5 \pm 0.8$ & $0.2 \pm 0.5$ & $0.260^{+}$ \\
\hline GDM history $\mathrm{n}(\%)$ & $5(17.8)$ & $2(8)$ & $0.290^{+}$ \\
\hline Family history of GDM n (\%) & $3(1.2)$ & $1(4)$ & $0.317^{+}$ \\
\hline Smoking n (\%) & $3(1.2)$ & $2(8)$ & $0.978^{+}$ \\
\hline Systolic blood pressure $(\mathrm{mmHg})$ & $116 \pm 14$ & $110 \pm 13$ & $0.123^{+}$ \\
\hline Diastolic blood pressure $(\mathrm{mmHg})$ & $72 \pm 11$ & $64 \pm 8$ & $0.009^{*}$ \\
\hline Fasting blood glucose (mg/dl) & $94 \pm 16$ & $82 \pm 10$ & $0.003^{+}$ \\
\hline 50-g OGTT 1st hour (mg/dl) & $176 \pm 23$ & $123 \pm 26$ & $<0.001^{\dagger}$ \\
\hline 100-g OGTT 1st hour (mg/dl) & $189 \pm 13$ & $144 \pm 12$ & $<0.001^{+}$ \\
\hline 100-g OGTT 2nd hour (mg/dl) & $152 \pm 17$ & $125 \pm 12$ & $0.006^{+}$ \\
\hline 100-g OGTT 3rd hour (mg/dl) & $115 \pm 19$ & $103 \pm 20$ & $0.151^{+}$ \\
\hline Serum creatinine (mg/dl) & $0.5 \pm 0.1$ & $0.5 \pm 0.1$ & $0.946^{+}$ \\
\hline
\end{tabular}

*Mann-Whitney U test; ' Independent samples t-test. 
Table 2. Transthoracic echocardiographic findings of study population.

\begin{tabular}{lccc} 
& $\begin{array}{c}\text { GDM group }(\mathbf{n}=\mathbf{2 8}) \\
\text { Mean } \pm \text { SD }\end{array}$ & $\begin{array}{c}\text { Control group ( } \mathbf{n}=\mathbf{2 5}) \\
\text { Mean } \pm \text { SD }\end{array}$ & p-value \\
\hline EF $(\%)$ & $63 \pm 2.6$ & $62 \pm 2.8$ & $0.334^{*}$ \\
\hline Aortic systolic diameter $(\mathrm{mm})$ & $2.5 \pm 2.4$ & $2.4 \pm 2.4$ & $0.292^{+}$ \\
\hline Aortic diastolic diameter $(\mathrm{mm})$ & $2.3 \pm 2.5$ & $2.2 \pm 2.3$ & $0.155^{+}$ \\
\hline AD & $0.4 \pm 0.3$ & $0.5 \pm 0.2$ & $0.285^{+}$ \\
\hline AS (\%) & $6.3 \pm 0.7$ & $11.1 \pm 3.7$ & $0.415^{+}$ \\
\hline ASI & $9.6 \pm 7.3$ & $0.336 \pm 0.1$ & $0.079^{+}$ \\
\hline EFTT $(\mathrm{cm})$ & $0.416 \pm 0.1$ & $<0.001^{+}$ \\
\hline
\end{tabular}

AD: aortic distensibility; AS: aortic strain; ASI: aortic stiffness index; EF: ejection fraction; EFTT: epicardial fat tissue thickness. * Mann-Whitney U test; ${ }^{+}$Independent samples t-test.

groups ( $\mathrm{p}=0.079)$. There was no difference in left ventricular diameters of the groups in terms of ejection fraction. Aortic measurement units such as aortic systolic diameter, aortic diastolic diameter, AD, AS, ASI were similar between the groups (Table 2).

To further explore the independent predictor(s) of GDM, regression analysis was performed based on risk factors affecting GDM (Table 3). After adjusting for all covariates, EFTT was independently associated with GDM [odds ratio $(\mathrm{OR})=2.166,95 \%$ confidence interval $(\mathrm{CI})=1.063-4.399, \mathrm{p}=0.019]$.

\section{Discussion}

In our research, EFTT was significantly higher in patients with gestational diabetes mellitus. However, there was no significant difference in aortic stiffness measurements between two groups.

In recent studies, it has been reported that EFTT measurement by transthoracic echocardiography can be utilized as an early sign of increased cardiovascular risk. Many studies have found increased EFTT associated with metabolic syndrome and coronary heart disease. ${ }^{[12,23-25]}$ Prior researches revealed a significant associ-

Table 3. Independent predictors of gestational diabetes in multivariate logistic regression analysis.

\begin{tabular}{lccc} 
Variables & $\begin{array}{c}\text { Odds } \\
\text { ratio }\end{array}$ & $\begin{array}{c}\mathbf{9 5 \%} \text { confidence } \\
\text { interval }\end{array}$ & p-value \\
\hline Body mass index & 1.177 & $0.982-1.410$ & 0.077 \\
\hline Diastolic blood pressure & 1.035 & $0.961-1.115$ & 0.360 \\
\hline EFTT & 2.166 & $1.063-4.399$ & 0.019 \\
\hline
\end{tabular}

EFTT: epicardial fat tissue thickness. ation between EFTT, fasting blood glucose and DM. ${ }^{[12,26,27]}$ In the study of Çalışkan et al., the relationship between EFTT and glucose intolerance in women with GDM history was investigated. EFTT measured by echocardiography was found to be significantly increased in 62 women with previous GDM compared to the control group ${ }^{[2]}$ In this research, it was reported that high EFTT may indicate the existence of atherosclerosis in women with prior GDM. In another study, the mean EFTT was detected higher in pregnant women with GDM compared to the control group. In the same study, significant correlations were found between EFTT, BMI and postprandial serum glucose levels. ${ }^{[2]}$ These results were comparable with another study that showed that postprandial glucose and BMI are associated with maternal EFTT in regression models. ${ }^{[13]}$ In a recent systematic review and meta-analysis, each unit increment in BMI $\left(\mathrm{kg} / \mathrm{m}^{2}\right)$ was associated with a higher risk of coronary heart disease in women. ${ }^{[30]}$ Also obesity is a major risk factor for Type $2 \mathrm{DM}$, in fact, $85.2 \%$ of people with Type 2 DM are overweight or obese. ${ }^{[3]}$ As expected, BMI of the GDM group was higher in our study.

Yavuz et al. measured both maternal and fetal EFTT in pregnant women with GDM at the second trimester, and fetal and maternal EFTT were found to be significantly higher in patients with GDM compared to nongestational diabetes mellitus. ${ }^{[14]}$ In addition, fetal EFTT was measured by fetal echocardiography in this study. It was determined that fetal EFTT was an independent predictor for serum glucose values after glucose tolerance test. In our study, the increased EFTT rates in gestational diabetic women support these data.

In a prospective study conducted by Moodley et al., it was shown that pregnant women with pregestational and gestational diabetes mellitus had more arterial 
stiffness compared to non-diabetic pregnant women, but this variability did not cause a deterioration in placental or fetal cardiovascular parameters. ${ }^{[32]}$ In our study, no difference was found between the two groups in terms of arterial stiffness. The reason for not showing a difference between the study and control groups in terms of arterial stiffness may be that the cardiovascular evaluation of the patients with gestational diabetes mellitus was performed as soon as they were diagnosed. However, despite this, the difference between the two groups in terms of EFTT without arterial involvement in our study shows that EFTT may stand out as an early marker.

In the study of Altmet et al. conducted in 44 cases with gestational hypertension and 46 healthy pregnant women, maternal EFTT was higher than the control group, but the carotid intima-media thickness was not different between the two groups. ${ }^{[3]]}$ Patients with gestational diabetes were excluded in this study. However, we found similar results with Altmet et al.'s study. This result may have been caused by the presence of the risk factors of gestational diabetes mellitus that predispose to gestational hypertension in these patients in our study.

The limitation of our study is that patients cannot be categorized in terms of treatment modalities after diagnosis of GDM and cannot be evaluated with cardiovascular examinations at regular intervals according to this categorization. The EFTT, AD, AS, ASI are the parameters that have been studied in the literature in terms of cardiovascular risk assessment in pregnant women with gestational diabetes mellitus. According to the results of our study, EFTT was found to be statistically significantly higher in pregnant women with gestational diabetes compared to the control group, but the fact that no difference was detected in other cardiovascular parameters suggests that EFTT may be an early diagnostic tool for GDM that can be checked before gestational diabetes mellitus screening.

\section{Conclusion}

In conclusion, BMI and EFTT were higher in GDM group but only EFTT was independent predictor of GDM. Screening of groups at risk for GDM with EFTT at the beginning of pregnancy may improve treatment modalities that can help to intervene before cardiovascular damage occurs. Randomized prospective studies are needed to use EFTT as a cardiovascular parameter at the beginning of pregnancy or after GDM detection.
Funding: This work did not receive any specific grant from funding agencies in the public, commercial, or not-for-profit sectors.

Compliance with Ethical Standards: The authors stated that the standards regarding research and publication ethics, the Personal Data Protection Law and the copyright regulations applicable to intellectual and artistic works are complied with and there is no conflict of interest.

\section{References}

1. Wendland EM, Torloni MR, Falavigna M, Trujillo J, Dode MA, Campos MA, et al. Gestational diabetes and pregnancy outcomes - a systematic review of the World Health Organization (WHO) and the International Association of Diabetes in Pregnancy Study Groups (IADPSG) diagnostic criteria. BMC Pregnancy Childbirth 2012;31:23. [PubMed] [CrossRef]

2. Peker A, Yarkıcı H, Akar H. Current approaches in gestational diabetes mellitus. The European Research Journal 2019; 5:382-8. [CrossRef]

3. American Diabetes Association. Diagnosis and classification of diabetes mellitus. Diabetes Care 2009;32 Suppl 1:S62-S67. [PubMed] [CrossRef]

4. Noussitou P, Monbaron D, Vial Y, Gaillard RC, Ruiz J. Gestational diabetes mellitus and the risk of metabolic syndrome: a population-based study in Lausanne, Switzerland. Diabetes Metab 2005;31:361-9. [PubMed] [CrossRef]

5. Vounzoulaki E, Khunti K, Abner SC, Tan BK, Davies MJ, Gillies CL. Progression to type 2 diabetes in women with a known history of gestational diabetes: systematic review and meta-analysis. BMJ 2020;369:m1361. [PubMed] [CrossRef]

6. Shah BR, Retnakaran R, Booth GL. Increased risk of cardiovascular disease in young women following gestational diabetes mellitus. Diabetes Care 2008;31:1668-9. [PubMed] [CrossRef]

7. Kremen J, Dolinkova M, Krajickova J, Blaha J, Anderlova K, Lacinova Z, et al. Increased subcutaneous and epicardial adipose tissue production of proinflammatory cytokines in cardiac surgery patients: possible role in postoperative insulin resistance. J Clin Endocrinol Metab 2006;91:4620-7. [PubMed] [CrossRef]

8. Sacks HS, Fain JN, Holman B, Cheema P, Chary A, Parks F, et al. Uncoupling protein-1 and related messenger ribonucleic acids in human epicardial and other adipose tissues: epicardial fat functioning as brown fat. J Clin Endocrinol Metab 2009;94:3611-5. [PubMed] [CrossRef]

9. Marchington JM, Pond CM. Site specific properties of pericardial and epicardial adipose tissue: the effects of insulin and high-fat feeding on lipogenesis and the incorporation of fatty acids in vivo. Int J Obes 1990;14:1013-22. [PubMed]

10. Cetin M, Cakici M, Polat M, Suner A, Zencir C, Ardic I. Relation of epicardial fat thickness with carotid intimamedia thickness in patients with type 2 diabetes mellitus. Int J Endocrinol 2013;2013:769175. [PubMed] [CrossRef]

11. Altun B, Tasolar H, Eren N, Binnetoğlu E, Altun M, Temiz A, et al. Epicardial adipose tissue thickness in hemodialysis patients. Echocardiography 2014;31:941-6. [PubMed] [CrossRef] 
12. Ahn SG, Lim HS, Joe DY, Kang SJ, Choi BJ, Choi SY, et al. Relationship of epicardial adipose tissue by echocardiography to coronary artery disease. Heart 2008;94:e7. [PubMed] [CrossRef]

13. Nar G, Inci S, Aksan G, Unal OK, Nar R, Soylu K. The relationship between epicardial fat thickness and gestational diabetes mellitus. Diabetol Metab Syndr 2014;6:120. [PubMed] [CrossRef]

14. Yavuz A, Akkurt MO, Yalcin S, Karakoc G, Varol E, Sezik M. Second trimester fetal and maternal epicardial fat thickness in gestational diabetic pregnancies. Horm Metab Res 2016 Sep;48(9):595-600. [PubMed] [CrossRef]

15. Arnett DK, Evans GW, Riley WA. Arterial stiffness a new cardiovascular risk factor. Am J Epidemiol 1994;140:669-82. [PubMed] [CrossRef]

16. Park HE, Choi SY, Kim HS, Kim MK, Cho SH, Oh BH. Epicardial fat reflects arterial stiffness: assessment using 256slice multidetector coronary computed tomography and cardio-ankle vascular index. J Atheroscler Thromb 2012;19: 570-6. [PubMed] [CrossRef]

17. Asmar R, Benetos A, Topouchian J, Laurent P, Pannier B, Brisac AM, et al. Assessment of arterial distensibility by automatic pulse wave velocity measurement. Validation and clinical application studies. Hypertension 1995;26:485-90. [PubMed] [CrossRef]

18. Lehman ED, Parker JR, Hopkins GD, Taylor MG, Gosling RG. Validation and reproductibility of pressure-corrected aortic distensibility measurements using pulse-wave-velocity Doppler ultrasound. J Biomed Engl 1993;15:221-8. [PubMed] [CrossRef]

19. Lacombe F, Dart A, Dewar E, Jennings G, Cameron J, Laufer E. Arterial elastic properties in man: a comparison of echo-Doppler indices of aortic stifnes. Eur Heart J 1992;13: 1040-5. [PubMed] [CrossRef]

20. National Diabetes Data Group. Classification and diagnosis of diabetes mellitus and other categories of glucose intolerance. Diabetes 1979;28:1039-57. [PubMed] [CrossRef]

21. Iacobellis G, Willens HJ. Echocardiographic epicardial fat: a review of research and clinical applications. J Am Soc Echocardiogr 2009;22:1311-9. [PubMed] [CrossRef]

22. Laurent S, Boutouyrie P, Asmar R, Gautier I, Laloux B, Guize $\mathrm{L}$, et al. Aortic stiffness is an independent predictor of all-cause and cardiovascular mortality in hypertensive patients. Hypertension 2001;37:1236-41. [PubMed] [CrossRef]

23. Iacobellis G, Ribaudo MC, Assael F, Vecci E, Tiberti C, Zappaterreno A, et al. Echocardiographic epicardial adipose tis- sue is related to anthropometric and clinical parameters of metabolic syndrome: a new indicator of cardiovascular risk. J Clin Endocrinol Metab 2003;88:5163-8. [PubMed] [CrossRef]

24. Nakazato R, Dey D, Cheng VY, Gransar H, Slomka PJ, Hayes SW, et al. Epicardial fat volume and concurrent presence of both myocardial ischemia and obstructive coronary artery disease. Atherosclerosis 2012;221:422-6. [PubMed] [CrossRef]

25. Iacobellis G, Zaki MC, Garcia D, Willens HJ. Epicardial fat in atrial fibrillation and heart failure. Horm Metab Res 2014; 46:587-90. [PubMed] [CrossRef]

26. Sengul C, Cevik C, Ozveren O, Oduncu V, Sunbul A, Akgun $\mathrm{T}$, et al. Echocardiographic epicardial fat thickness is associated with carotid intima-media thickness in patients with metabolic syndrome. Echocardiography 2011;28:853-8. [PubMed] [CrossRef]

27. Iacobellis G, Barbaro G, Gerstein HC. Relationship of epicardial fat thickness and fasting glucose. Int J Cardiol 2008; 128:424-6. [PubMed] [CrossRef]

28. Caliskan M, Caklili OT, Caliskan Z, Duran C, Çiftçi FC, Avci $\mathrm{E}$, et al. Does gestational diabetes history increase epicardial fat and carotid intima media thickness? Echocardiography 2014; 31:1182-7. [PubMed] [CrossRef]

29. Nar G, Inci S, Aksan G, Unal OK, Nar R, Soylu K. The relationship between epicardial fat thickness and gestational diabetes mellitus. Diabetol Metab Syndr 2014;6:120. [PubMed] [CrossRef]

30. Mongraw-Chaffin ML, Peters SA, Huxley RR, Woodward M. The sex-specific association between BMI and coronary heart disease: a systematic review and meta-analysis of 95 cohorts with 1.2 million participants. Lancet Diabetes Endocrinol 2015;3:437-49. [PubMed] [CrossRef]

31. Centers for Disease Control and Prevention (CDC). Report CMaMW. Prevalence of overweight and obesity among adults with diagnosed diabetes - United States, 1988-1994 and 1999-2002. MMWR Morb Mortal Wkly Rep 2004;53: 1066-8. [PubMed]

32. Moodley S, Arunamata A, Stauffer KJ, Nourse SE, Chen A, Quirin A, et al. Maternal arterial stiffness and fetal cardiovascular physiology in diabetic pregnancy. Ultrasound Obstet Gynecol 2018;52:654-61. [PubMed] [CrossRef]

33. Altin C, Yilmaz M, Ozsoy HM, Gezmis E, Balci S, Tekindal MA, et al. Assessment of epicardial fat and carotid intima media thickness in gestational hypertension. J Obstet Gynaecol Res 2018;44:1072-9. [PubMed] [CrossRef]

This work is licensed under the Creative Commons Attribution-NonCommercial-NoDerivs 4.0 Unported (CC BY-NC-ND4.0) License. To view a copy of this license, visit http://creativecommons.org/licenses/by-nc-nd/4.0/ or send a letter to Creative Commons, PO Box 1866, Mountain View, CA 94042, USA.

Publisher's Note: The content of this publication does not necessarily reflect the views or policies of the publisher, nor does any mention of trade names, commercial products, or organizations imply endorsement by the publisher. Scientific and legal responsibilities of published manuscript belong to their author(s). The publisher remains neutral with regard to jurisdictional claims in published maps and institutional affiliations. 